\title{
The Effectiveness of Dramaturgy in Teaching English as a Second Language in Senior High School Students
}

\author{
Rita Sutjiati Johan \\ English Department \\ Gunadarma University \\ Jakarta, Indonesia \\ ritadjohan@staff.gunadarma.ac.id
}

\begin{abstract}
Dramaturgy is one of the unique shapes of education that Indonesian students could have in learning English. The purpose of this study is to investigate the differences of English ability between two classes of second grade in private senior high school in Depok, West Java by using dramaturgy in teaching English. The research involved 52 pupils in experiment class and 54 pupils in control class. The experiment class used the dramaturgy in teaching English, while the control class did not use it. In the beginning of the study they were given preliminary English test and by the end of the year they were given the final English test. All statistical analyses were conducted using STATA 14 statistical software. The result of the study showed that the mean English test score of the experiment class was significantly higher than that of the control class $(p=0.00)$. It is concluded that dramaturgical practices are useful to aid the students to study English.
\end{abstract}

Keywords: dramaturgy, English teaching

\section{INTRODUCTION}

English is not easy to learn for most Indonesian people. Some Asian countries, taking advantages of being Britain's or USA's colonies in the past, may have older generations which have adopted some English culture and can speak English relatively fluently. At least, these may help their younger generation to study English. Indonesia however, has endured long period of harsh Dutch colonization, which allowed a very tiny fraction of Indonesian people to get education. A diminutive part Indonesian elderly then can speak Dutch, but not English. Learning a language needs a lot of practice. So mostly younger Indonesian people cannot practice their English at home, as their parents are not familiar with English speaking.

Dramaturgy is the theory and practice of dramatic composition. The issue to narrow the perspective of teaching English through drama has evolved remarkably over the last seventy years [1]. Proper study of any foreign language means the student also has to study some aspect of its culture. Hence it is natural that if someone study English, he or she is also being introduced to some dramatic compositions in English. However, I aim at more than that, i.e. practicing the dramatic composition perhaps may aid the students to learn English more effectively.

This study is intended to reveal whether dramaturgy, i.e. practicing English dramatic compositions might increase Indonesian senior high school students' ability in English.

\section{METHODS}

Two classes of second grade students of a private senior high school in Depok, West Java, were chosen to conduct the study. Some demographic variables were collected to get a clear description of the sample's characteristics. The experiment began at the beginning of educational year, to be performed in one whole year. The first class would be the experiment class, while the second one is the control class. At the beginning, students of both classes would have undergone English test, to make sure that the average abilities in English between the two classes were balanced. A statistical test will be performed to analyze whether there is any difference in the mean scores between the two classes.

Then, during a whole year the students of experiment class had to practice a variety of English dramatic compositions beside their conventional English class. The control class only had conventional English class, though its total English hours is the same as conventional English plus dramatic practices in the experiment class. Although classical English dramatic compositions were chosen to be practiced, the teachers had to use modern English words instead of archaic ones. To encourage students' enthusiasm, the school even organized classical English dramatic show two times during the experiment. At end of the year, again students of both classes would undergo English test to check their annual advances in studying English. A statistical test would be done to check whether there was any significant difference between the means English scores of the two classes, adjusting for the preliminary English scores. 
All statistical analyses will be conducted using STATA 14 statistical software.

\section{RESULTS}

The experiment class has 52 students, while the control one has 54 students. Their demographic characteristics is shown in Tabel I.

TABLE I. SOME DEMOGRAPHIC CHARACTERISTICS OF THE STUDENTS IN DRAMATURGY STUDY, DEPOK, 2015

\begin{tabular}{|c|c|c|c|c|c|c|c|}
\hline \multirow{2}{*}{ No } & \multirow{2}{*}{ Characteristic } & \multicolumn{2}{|c|}{ Experiment } & \multicolumn{2}{|c|}{ Control } & \multicolumn{2}{|c|}{ Total } \\
\hline & & $N$ & $\%$ & $N$ & $\%$ & $N$ & $\%$ \\
\hline 1 & $\begin{aligned} & \text { Age } \\
\leq & 17 \text { years } \\
> & 18 \text { years }\end{aligned}$ & $\begin{array}{l}30 \\
22\end{array}$ & $\begin{array}{l}57.7 \\
42.3\end{array}$ & $\begin{array}{l}29 \\
25\end{array}$ & $\begin{array}{l}53.7 \\
46.3\end{array}$ & $\begin{array}{l}59 \\
47\end{array}$ & $\begin{array}{l}55.7 \\
44.3\end{array}$ \\
\hline 2 & $\begin{array}{c}\text { Gender } \\
\text { Male } \\
\text { Female }\end{array}$ & $\begin{array}{l}24 \\
28\end{array}$ & $\begin{array}{l}46.2 \\
53.8\end{array}$ & $\begin{array}{l}25 \\
29\end{array}$ & $\begin{array}{l}46.3 \\
53.7\end{array}$ & $\begin{array}{l}49 \\
57\end{array}$ & $\begin{array}{l}46.2 \\
53.8\end{array}$ \\
\hline 3 & $\begin{array}{c}\text { Socio-economic status } \\
\text { High } \\
\text { Middle } \\
\text { Low }\end{array}$ & $\begin{array}{l}14 \\
20 \\
18\end{array}$ & $\begin{array}{l}26.9 \\
38.5 \\
34.6\end{array}$ & $\begin{array}{l}13 \\
22 \\
19\end{array}$ & $\begin{array}{l}24.1 \\
40.7 \\
35.2\end{array}$ & $\begin{array}{l}27 \\
42 \\
37\end{array}$ & $\begin{array}{l}25.5 \\
39.6 \\
34.9\end{array}$ \\
\hline 4 & $\begin{array}{c}\text { Parental main occupation } \\
\text { Civil servant } \\
\text { Soldier/Police } \\
\text { Private Employee } \\
\text { Entrepreneur } \\
\text { Others }\end{array}$ & $\begin{array}{c}4 \\
2 \\
15 \\
23 \\
8 \\
\end{array}$ & $\begin{array}{c}7.7 \\
3.8 \\
28.9 \\
44.2 \\
15.4\end{array}$ & $\begin{array}{c}6 \\
1 \\
12 \\
26 \\
9\end{array}$ & $\begin{array}{c}11.1 \\
1.9 \\
22.2 \\
48.1 \\
16.7\end{array}$ & $\begin{array}{c}10 \\
3 \\
27 \\
49 \\
17\end{array}$ & $\begin{array}{r}9.4 \\
2.8 \\
25.5 \\
46.2 \\
16.0\end{array}$ \\
\hline & Total & 52 & $100 \%$ & 54 & $\begin{array}{c}100 \\
\%\end{array}$ & 106 & $100 \%$ \\
\hline
\end{tabular}

Characteristics of the two classes are relatively nearly similar, there are no significant characteristic differences between the two classes. Preliminary results of English test are shown in Table II.

It can be seen in Table II, that there was no significant difference in the ability of English between the two classes at the beginning of experimentation.

By the end of the experimentation, a final English test is again performed with the results shown in Table III.

To compare the scores of final English test between the experiment and control classes, adjusting for the scores of preliminary English test, an Analysis of Covariance has been performed with results shown in Table IV.

TABLE II. RESULTS OF PRELIMINARY ENGLISH TEST, DRAMATURGY STUDY, DEPOK 2015

\begin{tabular}{|c|c|c|c|c|c|c|}
\hline No & Class & $\boldsymbol{N}$ & Mean & SE & 95\% CI & p-value \\
\hline 1 & Experiment & 52 & 63.08 & 0.52 & $62.03 ; 64.12$ & $p=$ \\
\hline 2 & Control & 54 & 63.09 & 0.55 & $62.00 ; 64.19$ & $0.49 *)$ \\
\hline & Total & 106 & 63.08 & 0.38 & $62.34 ; 63.83$ & \\
\hline
\end{tabular}

TABLE III. SUMMARY RESULTS OF POSTTEST ENGLISH SCORES FOR THE EXPERIMENTAL AND CONTROL CLASSES, DRAMATURGY

\begin{tabular}{|c|c|c|c|c|c|c|}
\hline No & Class & N & Mean & SD & Min & Max \\
\hline 1 & Experiment & 52 & 74.96 & 4.98 & 63 & 86 \\
\hline 2 & Control & 54 & 65.91 & 6.98 & 53 & 86 \\
\hline & Total & 106 & 70.35 & 7.57 & 53 & 86 \\
\hline
\end{tabular}

TABLE IV. ANOVA TABLE TO COMPARE POSTTEST ENGLISH SCORES BETWEEN EXPERIMENTAL AND CONTROL CLASSES ADJUSTING FOR PRETEST ENGLISH SCORES, DRAMATURGY STUDY, 2015

\begin{tabular}{|c|r|r|r|r|r|}
\hline $\begin{array}{c}\text { Source of } \\
\text { variation }\end{array}$ & $\boldsymbol{S S}$ & $\boldsymbol{d} \boldsymbol{f}$ & $\boldsymbol{M S}$ & $\boldsymbol{F}$ & $\boldsymbol{p}$-value \\
\hline Model & 2204.494 & 2 & 1102.247 & 29.79 & 0.0000 \\
\hline Class & 2172.7014 & 1 & 2172.7014 & 58.71 & 0.0000 \\
\hline Pretest & 32.8692 & 1 & 32.8692 & 0.89 & 0.3482 \\
\hline Residual & 3811.5909 & 103 & 37.0057 & & \\
\hline Total & 6016.0849 & 105 & 57.2960 & & \\
\hline
\end{tabular}

In the overall, $F$-test result in Table IV showed that there is significant differences between group means ( $p$-value for Model $=0.0000)$. After adjusting for pretest scores, $F$-test still showed significant difference between the experimental and control classes ( $p$-value for Class = 0.0000).

\section{DISCUSSION}

In this research, the author considers some factors that might affect the students' ability in learning and understanding English such as age, gender, socialeconomics status, parental main occupations. Based on the first table that consists of students from both the classes with 52 students and 54 students each,there are $57,7 \%$ and $53,7 \%$ students in the experiment and the control class that around 17 while the rest of them are above 18 years old. The socio-economic status itself is divided into high, middle and low with high around $25,5 \%$, middle about $39,6 \%$ and $34,9 \%$ for the low. The last factor of the consideration is parental main occupation that is subdivided into $9,4 \%$ civil servant, $2,8 \%$ soldier or police, $25,5 \%$ private employee, $46,2 \%$ entrepreneur and the rest $16 \%$ is for other occupations.

Based on the observations made by the author in a private school in Depok, West Java, the author finds a significant difference between the two trial classes which are experiment class and control class. According to the results of English test conducted before the materials are given to the classes, it appears that the average score (mean) in English subject in the experiment class with 52 students is 63.08 and the control class with 54 students is 63.09. The result of this dramaturgy methodology is quite consequential. The experiment class, which has to take the conventional and dramaturgy method has shown a significant change, from 63.08 to 74.96. However, the control class, which takes the conventional class only, has also shown some changes but not as significant as the experiment class. It goes from 63.09 to 65.91 .

Dramaturgical teaching has been described as the most student-centered course design structure available in the leadership/management education field [2]. As practitioners in the education field, Heathcote and Bolton have a tremendous way in making learning more interactive and student-active. Heathcote and Bolton proposed a mode of teaching that is not just about implementing the element drama but also an imaginative and integrated mode of learning. Heathcote and Bolton emphasize that role oriented learning is an interactive method [3]. Roleplaying as it is suggested, emphasizes on the role the students take as a way of achieving 
experiences in learning. Roleplaying enables the student to act on their own. Students must cooperate and collaborate which allows them to examine themselves. Role playing engage the students in an environment where students are demanded to perform various tasks and examine themselves based on the tasks that they have achieved. The students' examination on themselves are feedbacks that they will use as an empowerment and responsibility-building to become more aware of their own abilities in learning with the help of teachers to support them.

Within this method, though it may be a student-oriented method, the teachers are also placed as a significant motivator to the students. Students may work among themselves but the process of learning is not merely achieved by the students' efforts alone. Students and teachers will work together, although the center of learning is the students. Teachers role in this method is to evaluate, therefore creating an effective learning environment which are originated from the students' experience of learning itself. This research had proven that by using dramaturgy in teaching English to the senior high school students is an effective way.

Caliga pointed out in her study that drama make the lesson an integral process because is the content and the form of this process, by doing so, teacher has to discover different qualities of the student [4].

O'Neil emphasizes that "teacher in role is one of the most effective ways of beginning process drama" [1]. By working from within the drama, teacher and students are able to create a fictional world together, establishing imaginary situations, modelling appropriate behavior and language, assigning roles, directing scenario direction, and maintaining tension. The teacher in role brings the "students into active participation in the event".

Gintel's understanding of dramaturgy as cited from [5] is that;

\begin{abstract}
of leading ideas, ability to sensitively and carefully listen to needs, interests and ideas of future participants.
\end{abstract}

Martin in [5] emphasizes the concept of the dramaturgy wave, used to balance the physical, creative, social, and reflective aspects of the course.

In this study, the experiment class with dramaturgical teaching has been shown to achieve superior results in English test score in comparison with the control class. The results of teaching English with dramaturgy will certainly also depends on a lot of other factors, which due to limitations in the study design, were not controlled in this study. Such other influencing factors include the teacher qualifications, improvisations in the dramaturgical performances of classical novels, opportunities for the students to cast their play in front of the audience, and many others.

\section{CONCLUSION}

The mean English test score of the experiment class was significantly higher than that of the control class ( $p=$ $0.00)$, hence it is concluded that dramaturgical practices are quite useful to aid the students to study English.

\section{References}

[1] G. Carkin, "Teaching English Through Drama: The State of the Art," viewed March 10, 2015, available from <http://evotesolddrama2011.pbworks.com/f/Teaching+English+th rough+Drama1.doc>, 2007.

[2] J.E. Barbuto, "Dramaturgical Teaching in the Leadership Classroom: Taking Experimental Learning to the Next Level," Journal of Leadership Education, vol 5(2) - Fall 2006: pp 4-13.

[3] C. O'Neil, "Foreword to Drama for Learning: Mantle of the Expert," viewed April 15, available from http://www.mantleoftheexpert.com/wp-content/uploads/2012/04, 2012.

[4] M. Caliga, "Systematical Approach of Integrality of Musical Didactical Activity through the Dramaturgy at Musical Education Lesson," viewed April 12, 2017, available from: <https://www.degruyter.com/downloadpdf/j/rae.2017.13.issue1/rae-2017-0002/rae-2017-0002.pdf>, 2017.

[5] J. Svoboda, A. Dvořáčková, M. Jirásková, M. Bolcková, \& P. Majewská, "Winter Course Experience: Towards a Wider Understanding of a Dramaturgy Approach," Acta Gymnica, 2015, vol 45(4): pp 167-76. 